\title{
In-vitro Evaluation of Some Plant Leaf Extract against Coconut Leaf Spot Caused by Pestalotia palmarum (Cooke) in Bastar Plateau of Chhattisgarh
}

\author{
Vandana Chadar*, R. R. Bhanwar, Rajendra Kashyap, \\ Shraddha Karcho and Luchika Rana
}

\begin{abstract}
Department of Plant Pathology, S. G. College of Agriculture and Research Station, Jagdalpur, IGKV, Chhattisgarh, 494001, India
\end{abstract}

*Corresponding author

A B S T R A C T

Keywords

Coconut leaf spot, plant leaf extract, In vitro, Pestalotia palmarum,

Poisoned food technique

Article Info

Accepted:

04 March 2020

Available Online:

10 April 2020
In the present investigation 30 Plant leaf extract were evaluated in in vitro condition against $P$. palmarum adopting poisoned food technique. The per cent inhibition of pathogen was 100 per cent by Dhatura, Anjwain and Tobacco at 10 per cent concentration followed by the turmeric (95.84), safed musli (90.62), garlic (87.5), hathjodh (86.5), kalmegh (86.46), jetropha (83.34), neem bark (79.18), satavar (78.12), lemongrass (69.81), laung (67.71), ashoka (65.62), aadusa (63.68), karanj bark (63.06), bhringraj (62.5), karanj (62.5), dalchini (61.15), beshram (60.43), brijdanti (57.46), arandi (56.25), neem (54.18), nilgiri (54.18), pattharchatta (52.09), tulsi (46.87), marigold (40.62) and aloevera (40.62) whereas the lowest inhibition was recorded in amari (Gangura) with 36.46 per cent.

\section{Introduction}

Coconut is one of the major plantation crop in india. Coconut tree (Cocos nucifera) is a member of the palm tree family (Arecaceae). In India, coconut farming is inseparably embedded in the socio-historical culture as well as the ethnic identity. Considering the versatile nature of the crop and the multi-uses of its products, the coconut palm is eulogized as Kalpavriksha (Tree of Heaven). In India with a total cultivated area of 1975.81 thousand hectares with a production of 21,665 million nuts which makes India stand 3rd in the world.

India occupies the premier position in the world with an annual production of 13 billion nuts, overtaking Indonesia and the Philippines, the other two prominent coconut-growing 
countries (Raghavi et al., 2019). Yield of the coconut also reduces day by day due to the causes of various diseases. Such as, sooty mould, stem bleeding, leaf spot, white thread blight, root rot, brown root rot and bud rot disease which are caused by different fungus. Among the diseases every year grey leaf spot disease caused by Pestalotia palmarum (Cooke.) attacks the gardens and decreases the growth and development of the tree as well as the yield of the fruit. The symptom is only developed in the mature leaves in the form of grayish white spots surrounded by brown margin. Several of the spots coalesce together and form irregular grey necrotic patches and show burnt or blighted appearances. The upper surface of the affected leaves reveals dark grey eruptions like pin heads. This disease is a serious problem all over the coconut growing regions of Bangladesh (Rahman et al., 2013).

\section{Materials and Methods}

\section{Collection of sample}

Diseased leaves of Coconut with typical leaf spot symptoms were collected from AICRP on Palms Research field of SGCARS, Jagdalpur (C.G.) (Fig. 2).

\section{Preparation of potato dextrose agar (PDA) medium}

The basic medium, PDA was prepared following the standard procedure (Anon. 1968). At first $200 \mathrm{~g}$ peeled potato is cut into slice and then boiled in $1000 \mathrm{ml}$ water. After that it was sieved and 15 gm agar were mixed with it in a water bath, after few minutes $20 \mathrm{~g}$ dextrose were mixed with it and stirred properly so that it cannot be coagulated. The $\mathrm{pH}$ was adjusted to 6.5 of the media by using $\mathrm{pH}$ meter with the help of $1 \mathrm{~N} \mathrm{HCL}$ and sterilized in autoclave at $121^{\circ} \mathrm{C}$ temperature for 20 minutes.

\section{Isolation of the fungus}

The fungus was isolated from the infected leaf of coconut following tissue planting technique (Tuite, 1969). The infected diseased samples along with healthy tissues were cut into small pieces and surface sterilized by dipping in $0.1 \%$ sodium hypochloride $(\mathrm{NaOCl})$ solution for two minutes. $\mathrm{NaOCl}$ on the surface of the leaf pieces was decanted by soaking with sterilized blotting paper. The cut pieces were then placed onto sterilized potato dextrose agar (PDA) in glass petridishes $(20 \mathrm{ml} /$ petridish) and incubated in an incubator at 27 $\pm 1^{\circ} \mathrm{C}$ until mycelium formation. The hyphal tips were transferred onto PDA plate after growing the mycelium.

\section{Identification of fungus}

The fungus was then identified on the basis the morphological of characteristics with the help of identifying key book (Barnett and Hunter, 1972).

\section{Purification}

To obtain pure culture of the pathogen, the hyphal tips were transferred aseptically onto PDA plate by using the flame sterilized tip of an inoculation needle. The plate was incubated at room temperature for seven days.

\section{Multiplication of $\boldsymbol{P}$. palmarum}

PDA was poured in sterilized petridishes, 25 $\mathrm{ml}$ in each. After solidification, the plates were inoculated by placing $5 \mathrm{~mm}$ discs of three days old PDA culture of $P$. palmarum. The discs were cut with flame sterilized cork borer (5 $\mathrm{mm}$ diameter). The inoculated petridishes were kept in the growth chamber at a temperature of $28 \pm 1^{\circ} \mathrm{C}$ for few days. All the works were undertaken under the laminar air flow cabinet. 


\section{Evaluation of different plant extract used in this experiment}

These plant extracts were tested initially under in-vitro condition by using poison food technique (Schmitz, 1930). The fresh leaves were grounded in a blender with distilled water. The extract was filtered through double layered muslin cloth. The extracts were tried at concentration of 10 per cent for seed treatment, prepared by diluting the extract in distilled water (Table 1).

Different plant extract were evaluated in in vitro condition against $P$. palmarum following poison food technique (Dhingra and Sinclair, 1985). All the plant extract were tested at recommended by adopting poisoned food technique. The test pathogen was grown on PDA medium in Petri plates for seven days prior to setting up of experiment. The required plant extract was added to the melted PDA medium to obtain the desired concentration.

$20 \mathrm{ml}$ of poisoned medium was poured in each Petri plate. Suitable checks were maintained without addition of fungicides. A mycelial disc of five $\mathrm{mm}$ diameter was taken from the periphery of 7 days old colony and placed in the centre and incubated at $28 \pm 2^{\circ} \mathrm{C}$ for full growth of the fungus.

Three replications were maintained for each treatment. The radial growth of the colony was measured in two directions and average was recorded. Per cent inhibition was recorded by using the formula given by Vincent (1947) as under:

$$
\mathrm{PI}=\left[\frac{(\mathrm{C}-\mathrm{T})}{\mathrm{C}}\right] \times 100
$$

Where,

$\mathrm{PI}=$ Per cent inhibition, $\mathrm{C}=$ Growth in control and $\mathrm{T}=$ Growth in treatment.

\section{Results and Discussion}

Among the 30 plant leaf extract were evaluated against coconut leaf spot $(P$. palmerum) adopting poisoned food technique. Observations of the radial growth of the pathogen were recorded after 7 day after inoculation. The percent inhibition of the pathogen over control was calculated and presented in Table 2, Fig. 3 and Chart 1. The superiority in controlling the inhibition of pathogen was managed by Dhatura, Anjwain and Tobacco inhibited the growth of $P$. palmarum was 100 per cent.

No growth was found at given concentration. the turmeric (95.84), safed musli (90.62), garlic (87.5), hathjodh (86.5), kalmegh(86.46), jetropha (83.34), neem bark (79.18), satavar (78.12), lemongrass (69.81), laung (67.71), ashoka (65.62), aadusa (63.68), karanj bark (63.06), bhringraj (62.5), karanj (62.5), dalchini (61.15), beshram (60.43), brijdanti (57.46), arandi (56.25), neem (54.18), nilgiri (54.18), pattharchatta (52.09), tulsi (46.87), marigold (40.62) and aloevera (40.62) whereas the lowest inhibition was recorded in amari (Gangura) with 36.46 per cent.

Islam et al., (2004) revealed that the two doses (4 and $5 \%$ ) of garlic extract were found most effective in inhibiting the redial growth of the fungus i. e. 88.76 per cent which favors the present study.

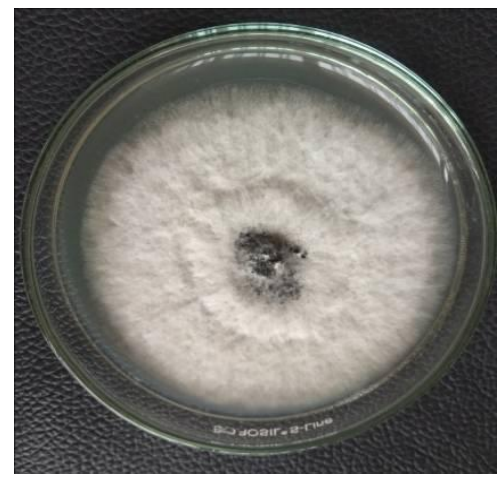

Fig.1 Pure culture of P. palmarum 
Table.1 List of botanicals used in the experiment

\begin{tabular}{|c|c|c|c|}
\hline S.N. & Treatment & Name of Botanicals & Botanical name \\
\hline 1. & $\mathrm{~T}_{1}$ & Tulsi & Ocimum tenuiflorum \\
\hline 2. & $\mathrm{~T}_{2}$ & Turmeric & Curcuma longa \\
\hline 3. & $\mathrm{~T}_{3}$ & Marigold & Tagetes spp. \\
\hline 4. & $\mathrm{~T}_{4}$ & Garlic & Allium sativam \\
\hline 5. & $\mathrm{~T}_{5}$ & Jetropha & Jatropha curcas \\
\hline 6. & $\mathrm{~T}_{6}$ & Dhatura & Datura stramonium \\
\hline 7. & $\mathrm{~T}_{7}$ & Caster & Ricinus communis \\
\hline 8. & $\mathrm{~T}_{8}$ & Pattharchatta & Bryophyllum pinnatum \\
\hline 9. & $\mathrm{~T}_{9}$ & Vringraj & Eclipta prostrate \\
\hline 10. & $\mathrm{~T}_{10}$ & Neem & Azadirachta indica \\
\hline 11. & $\mathrm{~T}_{11}$ & Karanj & Millettia pinnata \\
\hline 12. & $\mathrm{~T}_{12}$ & Neem bark & Azadirachta indica \\
\hline 13. & $\mathrm{~T}_{13}$ & Kalmegh & Andrographis paniculata \\
\hline 14. & $\mathrm{~T}_{14}$ & Satavar & Asparagus racemosus \\
\hline 15. & $\mathrm{~T}_{15}$ & Ashoka & Saraca asoca \\
\hline 16. & $\mathrm{~T}_{16}$ & Nilgiri & Eucalyptus spp. \\
\hline 17. & $\mathrm{~T}_{17}$ & Laung & Syzygium aromaticum \\
\hline 18. & $\mathrm{~T}_{18}$ & Anjwain & Trachyspermum ammi \\
\hline 19. & $\mathrm{~T}_{19}$ & Tobacco & Nicotiana tabacum \\
\hline 20. & $\mathrm{~T}_{20}$ & Lemongrass & Cymbopogan spp. \\
\hline 21. & $\mathrm{~T}_{21}$ & Beshram & Ipomoea carnea \\
\hline 22. & $\mathrm{~T}_{22}$ & Brijdanti & Banteria prionitis \\
\hline 23. & $\mathrm{~T}_{23}$ & Karanj bark & Millettia pinnata \\
\hline 24. & $\mathrm{~T}_{24}$ & Aloevera & Aloe barbadensis \\
\hline 25. & $\mathrm{~T}_{25}$ & Amari (Gangura) & Hibiscus sabdariffa \\
\hline 26. & $\mathrm{~T}_{26}$ & Aadusa & Justicia adhatoda \\
\hline 27. & $\mathrm{~T}_{27}$ & Dalchini & Cinnamamum verum \\
\hline 28. & $\mathrm{~T}_{28}$ & Safed musli & Chlorophytum borivilianum \\
\hline 29. & $\mathrm{~T}_{29}$ & Hathjodh & Cissus quadrangularis \\
\hline 30. & $\mathbf{T}_{30}$ & Control & Without phyto extract \\
\hline
\end{tabular}


Table.2 Percent inhibition of the radial growth of the pathogen of coconut leaf spot in in-vitro

\begin{tabular}{|c|c|c|}
\hline Treatment & $\begin{array}{c}\text { Mean growth }(\mathrm{mm}) \text { of } \\
\text { pathogens }\end{array}$ & $\begin{array}{l}\text { Percent inhibition of } \\
\text { pathogens }(\%)\end{array}$ \\
\hline $\mathbf{T}_{1}$ & 17.000 & 46.87 \\
\hline $\mathbf{T}_{2}$ & 01.333 & 95.84 \\
\hline $\mathbf{T}_{\mathbf{3}}$ & 19.000 & 40.62 \\
\hline $\mathbf{T}_{4}$ & 04.000 & 87.5 \\
\hline$T_{5}$ & 05.333 & 83.34 \\
\hline $\mathbf{T}_{6}$ & 00.000 & 100 \\
\hline $\mathbf{T}_{7}$ & 17.333 & 56.25 \\
\hline $\mathbf{T}_{8}$ & 15.333 & 52.09 \\
\hline $\mathbf{T}_{9}$ & 12.000 & 62.50 \\
\hline$T_{10}$ & 14.667 & 54.18 \\
\hline $\mathbf{T}_{11}$ & 12.000 & 62.50 \\
\hline $\mathbf{T}_{12}$ & 06.667 & 79.18 \\
\hline $\mathbf{T}_{13}$ & 06.667 & 86.46 \\
\hline $\mathbf{T}_{14}$ & 07.000 & 78.12 \\
\hline$T_{15}$ & 11.000 & 65.62 \\
\hline$T_{16}$ & 14.667 & 54.18 \\
\hline $\mathbf{T}_{17}$ & 10.333 & 67.71 \\
\hline$T_{18}$ & 00.000 & 100 \\
\hline$T_{19}$ & 00.000 & 100 \\
\hline$T_{20}$ & 09.667 & 69.81 \\
\hline $\mathbf{T}_{21}$ & 12.667 & 60.43 \\
\hline $\mathbf{T}_{22}$ & 13.667 & 57.46 \\
\hline $\mathbf{T}_{23}$ & 11.667 & 63.06 \\
\hline $\mathbf{T}_{24}$ & 19.000 & 40.62 \\
\hline $\mathbf{T}_{25}$ & 20.333 & 36.46 \\
\hline $\mathbf{T}_{26}$ & 11.667 & 63.68 \\
\hline $\mathbf{T}_{27}$ & 12.333 & 61.15 \\
\hline $\mathbf{T}_{28}$ & 03.000 & 90.62 \\
\hline $\mathbf{T}_{29}$ & 04.333 & 86.50 \\
\hline $\mathbf{T}_{\mathbf{3 0}}$ & 32.000 & - \\
\hline C.D at $5 \%$ & 4.339 & \\
\hline $\mathrm{SE}(\mathrm{m}) \pm$ & 1.530 & \\
\hline
\end{tabular}




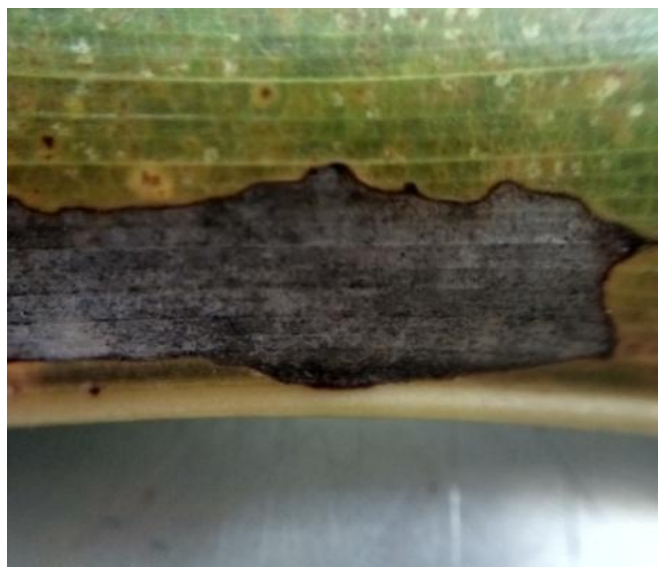

Fig.2 Infected coconut leaf

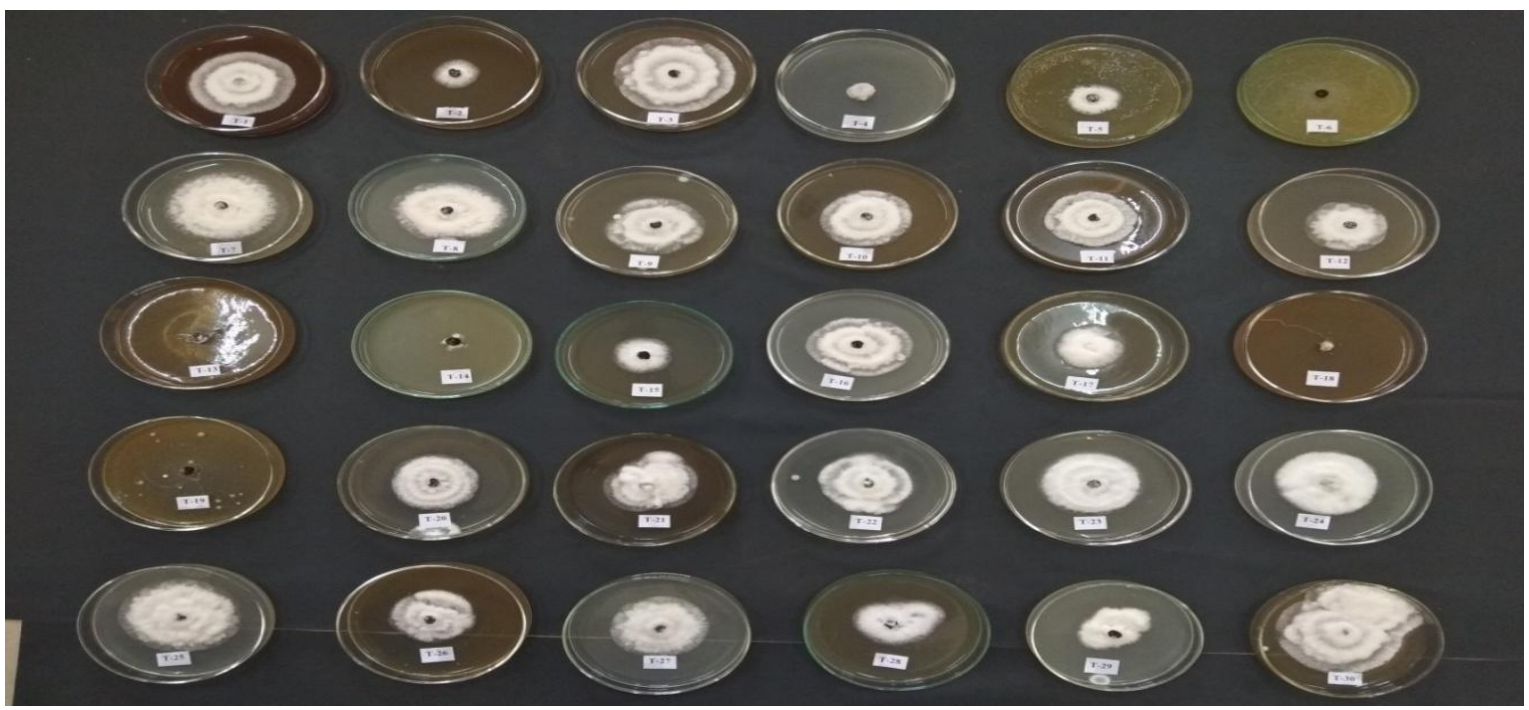

Fig.3 Effect of different plant leaf extract on $P$. palmarum

\section{Acknowledgement}

The author is grateful to acknowledge Mr. Rajesh Kumar Patel for providing technical guidance during entire course of work. The authors are also put sincere thanks to the AICRP on Palms, Jagdalpur and S. G. College of Agriculture and Research Station, Jagdalpur for proving necessary amenities during entire research of work.

\section{References}

Anonymous (1968) Plant Pathologist's Pocket Book. Commonwealth Mycological
Institute 394-395.

Barnett HL and Hunter BB. 1972. Illustrated Genera of imperfect Fungi. Burgess Publishing Company USA.

Dhingra, OD and Sinclair JB .1985. Basic Plant Pathology Methods. CRC Press, Boca Raton, USA.

Islam M.R., Hossain M.K., Bafar M.H. and Ali M.R. 2004. Identification of causal agent of leaf spot of betelnut and in vitro evaluation of fungicides and plant extract against it. Pakistan journal of biological science. 7(10): 1758-1761.

Raghavi. MD , Sakthi Balaa. M, Surender. S , Lokesh. P and Kalidas. K 2019. review 
on area, production and productivity of coconut in india. International Journal of Research in Business Management. 7(1):1-6.

Rahman S, Adhikary SK, Sultana S, Yesmin S, Jahan N. (2013) In vitro evaluation of some selected fungicides against Pestalotia palmarum (Cooke.) Causal Agent of Grey Leaf Spot of Coconut. J Plant Pathol Microb 4: 197 doi:10.4172/2157-7471.1000197
Schmitz H. 1930. A suggested body metric method for food preservation industries and engineering chem. Analyst $\mathrm{Ed}$ 3:361-365.

Tuite. 1969 Plant Pathological method; Fungi and Bacteria. Burgess Publishing Company, Inneapolis, Minn, USA.

Vincent JH. 1947. Distortion of Fungal Hyphae in the Presence of Certain Inhibitors. Nature, 15: 850.

\section{How to cite this article:}

Vandana Chadar, R. R. Bhanwar, Rajendra Kashyap, Shraddha Karcho and Luchika Rana. 2020. In-vitro Evaluation of Some Plant Leaf Extract against Coconut Leaf Spot Caused by Pestalotia palmarum (Cooke) in Bastar Plateau of Chhattisgarh. Int.J.Curr.Microbiol.App.Sci. 9(04): 218-224. doi: https://doi.org/10.20546/ijcmas.2020.904.026 